\title{
The Effect of Technology-Based Applications on Brand Image in the Telecommunications Industry
}

\author{
Husain Abdulaal, Muneer Mohammed Saeed Al Mubarak
}

\begin{abstract}
The paper investigates the effect of technology-based applications on brand image in the telecommunications industry. The study aims to identify the most influencing technology-based application on brand image and areas of improvements for each application. The study proposes a model that shows the effect of certain applications on brand image in the telecommunications industry. A quantitative survey was used for data collection to support the model. The research shows a significant overall model where technology-based applications account for $28 \%$ of variance in the consumer's perception of the brand image. Websites and social media applications have significant impact on brand image while mobile applications \& services have positive but insignificant impact on brand image. The paper can help companies to adopt technology-based applications in their brand management strategies and invest more on technology-based channels to enhance the brand image, attract more customers, and gain competitive advantage. There has been little research focusing on the effect of technology-based applications on the brand image and specifically in the telecommunications industry.

Keywords: Brands, Brand image, Technology-based applications, Websites, Mobile applications, Social media applications.
\end{abstract}

\section{INTRODUCTION}

Brand image is an important intangible asset for any organization and has become a high priority in top management strategic plans. It is a fundamental concept for marketers to study how customers think of a brand. The brand image is defined as the consumer's perceptions and preferences of a brand in his memory as reflected by brand connections and associations. Brand associations might include functional, experimental, or symbolic features and benefits of a product or service, or the whole evaluation of a brand (Keller, 2009). Brand Image is the summation of tangible and intangible perceptions, beliefs, and impression about the company's brand as perceived by customers. It includes an array of attributes that the consumers link with a brand name such as physical, emotional, and rational attributes (Balaji, 2011).

Revised Manuscript Received on December 30, 2019.

* Correspondence Author

Husain Abdulaal, Bachelor Degree in Computer Science from the University of Bahrain

Muneer Mohammed Saeed Al Mubarak, Associate Professor of Management and Marketing, VP for Admin \& Finance and Acting Dean of Student Affairs, at Ahlia University

(c) The Authors. Published by Blue Eyes Intelligence Engineering and Sciences Publication (BEIESP). This is an open access article under the CC BY-NC-ND license (http://creativecommons.org/licenses/by-nc-nd/4.0/)
The introduction of new technology-based applications including websites, mobile applications, and social media applications has dramatically affected how branding and brand management work in today's competitive marketplace. Traditional communications channels such as newspapers, magazines, brochures and television advertisements are losing their grasp on customers while the rapid dissemination of powerful technology tools such as high speed Internet connections, digital media players, smart cell phones and tablets have forced marketers to consider and adopt new technology-based and innovative communication channels instead of the obsolete traditional ones (Keller, 2009).

This research study investigates the effect of technology-based applications on brand image in the telecommunications industry. It examines the main technology-based applications that affect the brand image, determine the most influencing technology-based application, and identify the areas of improvement for each technology-based application examined in this study. Besides, only few studies were conducted on this matter and the literature lacks studying the effect of technology-based applications on brand image in a specific industry. This paper will significantly contribute to literature and will help firms to adopt technology-based applications in their brand management strategies, invest more on digital channels to improve the brand image, attract more customers, and subsequently gain competitive advantage over rivals.

The remainder of this paper is organized into six sections. First, we review related literature on brand image and technology-based applications that affect the brand image. Second, we present the conceptual model and research hypotheses. Third, we explain the research methodology used in this research study. Fourth, we present the study results and analysis including hypotheses testing. Fifth, we discuss the main study findings with relevant theoretical and managerial implications. Finally, we draw the conclusion along with suggestions for future research.

\section{LITERATURE REVIEW}

Academic researchers have spent considerable time and efforts in studying different topics related to brands and brand management and writing numerous articles about them. Nevertheless, less research studies were conducted and fewer articles were written about the effect of technology-based applications on brand image (Merrilees and Fry, 2002). The term "Brand Image" has been defined differently in literature by different researchers over time. 
Dichter (1985) argued that brand image describes the total feelings, thoughts, impressions, dispositions, and attitudes that a product makes on the minds of customers. According to Dobni and Zinkhan (1990), the brand image is an intuitive and subjective concept which is shaped by consumer's understanding, whether rational or emotional. It is not characterized by the physical and technical aspects of the product only, but also by marketing activities as well as by the perceptions of consumers. The brand image is described as a subjective perception of functional as well as non-functional information about a product or service (Chen and Myagmarsuren, 2011). The brand image "is the combination of consumers' perceptions and beliefs regarding a brand as it is the belief of consumers which makes a brand trustworthy and likable" (Kalra, 2016, p.24).

Brands govern what customers think of a company and its services, products, marketing campaigns, and communications. In other words, brands affect the firm ability to form its future (Jones and Bonevac, 2013). Brands play an important role in building a strong and long-term relationship between the firm and the customer that adds value to the customer, the firm, and the trade (Balaji, 2011). Brands provide benefits for both customers and firms. From customers' side, they help them in identifying the products or services they like or do not like, thus facilitating their purchase decisions and reducing the time required to purchase the product or service. In addition, they help customers in evaluating and judging the quality of the products offered by the firm. On the other side, firms benefit from brands because they facilitate promotional efforts and help in introducing new products and services within short timeline because existing brand is already well-known for customers (Eid et al., 2011). A strong brand is crucial for firms' long term success and competitive advantage over rivals in the marketplace that will improve their credibility and reputation (Ansari and Riasi, 2016; Kalra, 2016). Chen and Myagmarsuren (2011) suggested that another advantage of strong brands is that they are more accessible into customers' consideration sets as customers start their search for a product or a service with well-known brands which satisfy their needs. Customers who do not have ideas about the company's products or services make use of the brand image to infer the level of the quality of the service or product. According to (Broyles et al., 2009), when a brand becomes well known and accepted in the minds of customers, they link it to a bundle of positive expectations and advantages such as reliability, quality, and trust. With the highly aggressive competition in today's marketplace, many organizations have realized that building a strong brand image has become an essential strategy to gain a sustainable competitive advantage over rivals (Balaji, 2011; Janonis and Virvilaite, 2007). Because customer's attitude and reaction toward the company's brand image is a crucial determinant of business success, majority of companies spend huge amounts of money and devote ample resources to improve and strengthen their brand image (Ansari and Riasi, 2016). Keller (2001) suggested that building and developing a strong brand includes four main steps: establish depth and breadth of brand awareness, create brand meaning via unique and strong brand associations, obtain positive brand responses from customers, and finally build brand relationships with customers through strong and active loyalty. There are multiple theories and theoretical frameworks in marketing that are used to explain and describe the branding process, and the adoption or use of technology in marketing and branding. These theories were used by scholars in literature to conduct studies to investigate and explain how to build strong brands and examine how the adoption and use of technology can influence the customers' behavior or perceptions of brands. The most widely used theories and theoretical models in literature are: Customer-Based Brand Equity (CBBE) by Keller (2001), Technology Acceptance Model (TAM) by Davis (1989), and Brand Triangle Framework in Online Context by De Chernatony and Christodoulides (2004). The CBBE model has been widely used in empirical studies to examine the factors affecting the brand image in online contexts (Balaji, 2011; Wang and Li, 2012; Schivinski and Dabrowski, 2016). In addition, TAM has been widely used in literature as the theoretical framework for various marketing studies. Recent applications of TAM model have extended to investigate the impact of technology on different aspects including customers' behavior, satisfaction, loyalty, and brand image in online contexts (Morgan-Thomas and Veloutsou, 2013; Wang and Li, 2012, Rohm et al., 2012, Chen and Ching, 2007). Various research studies were conducted to investigate the effect of technology factors or technology-based applications on the brand image. According to former empirical studies, the most widely used technology constructs are websites, mobile applications \& mobile services, and social media applications. Hence, this research paper will primarily focus on those three technology-based applications. Due to information and communication technology advancement, the necessity to have a website with variety of online services has emerged to improve the customer experience and enhance the company's brand image by promoting a bundle of products and services associated with the brand name (Morgan-Thomas and Veloutsou, 2013). Online brand experience through website creates emotional connection between customers and the company's brand which lead to improved brand image (Cleff et al., 2018; Lin and Lee, 2012). Through websites, companies can reflect customer's values, interests, and behavior which will result in improving the brand awareness and creating a strong brand image (Keller, 2009). In addition, the online environment opens the doors for real-time experience, engagement with the brand, and interactivity between customers and others (Morgan-Thomas and Veloutsou, 2013). Companies invest substantial resources to enhance their websites layout, content, and products and services presentation techniques to further improve the customer experience with the company's brand (Kwon and Lennon, 2009). Positive online experience will result in customer's satisfaction, customer's intention to reuse the website, re-purchase of products, and renewal of subscriptions to services (Kollmann and Suckow, 2008).

With the extensive adoption of smart mobile devices among customers, the useful employment of mobile applications and services has emerged as an important tactic in brand management (Rohm et al., 2012). They are powerful technology tools to improve the brand image by providing direct and interactive experience with the company's products and services, which affects the customers' perception of the brand (Rondeau, 2005).

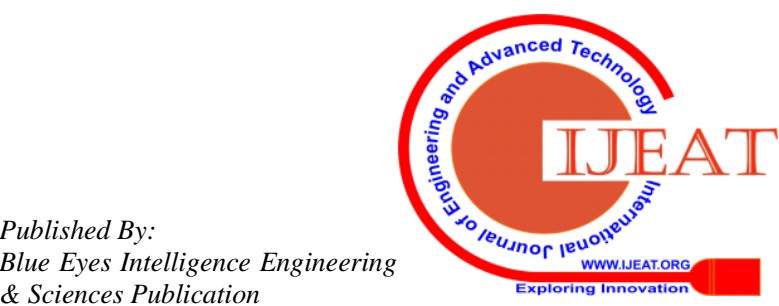


The brand image is affected by mobile applications and services as they have strong effect on satisfying customers' expectations and needs (Chen and Ching, 2007). Furthermore, providing mobile services and mobile applications will satisfy the customers' needs, engage them with the brand, and enhance the brand image (Wang and $\mathrm{Li}$, 2012). The extra value added by mobile applications and mobile services is resulting from being easily accessible irrespective of location and time, and being easily customized based on time, location, and personal preferences (Strom et al., 2014). In addition, handling customer service issues and providing customer care support are other positive aspects of having mobile applications and other mobile services where customers' queries about the brand products or services are answered, and secure payments can be made instantly and conveniently (Strom et al., 2014).

One of the most powerful and important marketing tools is social media applications. Most companies have started adopting social media marketing strategies to improve the brand image impression towards the target customers. Social Media Applications are new interactive technology tools that build virtual communities, create emotional experiences, and help companies to enhance their brand image (Erdogmus and Cicek, 2012). By using social media applications, companies can easily promote their products and services to a large group of customers, receive instant feedback, and provide immediate online support (Kaplan and Haenlein, 2010). The real-time interaction and communication between customers and the company through social media applications create a good opportunity to increase brand awareness and improve the brand image (Mangold and Faulds, 2009). Moreover, customers regularly consider other customers' comments, reviews, and feedback about products or services before purchase as electronic word of mouth affects the brand image and purchasing behavior significantly (Torlak et al., 2014). Companies should include social media applications in their marketing plans and strategies to provide real-time information, engage with consumers, and increase sales (Tiago and Verissimo, 2014).

\section{CONCEPTUAL MODEL AND RESEARCH HYPOTHESES}

The conceptual model for this research study is developed based on the empirical studies discussed in literature review. The conceptual framework is made up of three independent variables which are Websites, Mobile Applications \& Services, and Social Media Applications, and one dependent variable which is Brand Image. For this study, we develop a model that aims to investigate the impact of technology-based application on brand image as illustrated in Figure 1. Therefore, we formulate three research hypotheses which are explained in the following sections.

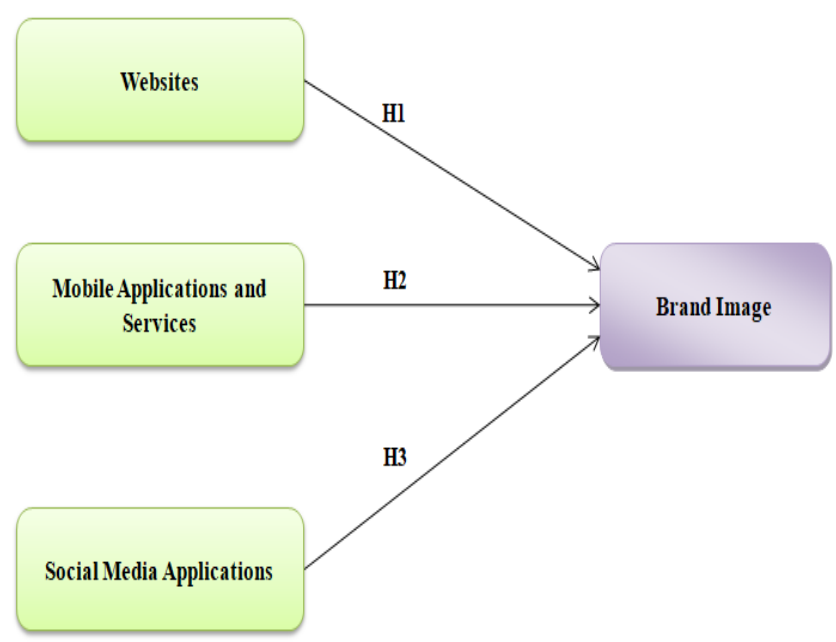

Figure 1. Conceptual Model

\subsection{Websites}

Websites and online services help companies in improving the customer experience as well as the interactive engagement with the brand that will improve the company's brand image consequently (Morgan-Thomas and Veloutsou, 2013; Kwon and Lennon, 2009). Websites create emotional connection between customers and the company's brand through interactive experience with the brand which lead to improved brand image (Cleff et al., 2018). Through websites, companies can reflect customer's values, interests, and behavior which will result in creating a strong brand image (Keller, 2009). If the level of interaction increased between customers and the brand through websites and online environment, the emotional connection and experience between the customer and the firm will increase and this will lead to more brand recognition by customers (Lin and Lee, 2012). Positive online experience will result in customer's satisfaction, customer's intention to reuse the website, re-purchase of products, and renewal of subscriptions to services (Kollmann and Suckow, 2008). Therefore, we can hypothesize that:

H1. Websites have a significant impact on brand image.

\subsection{Mobile Applications \& Services}

Mobile applications and mobile services are powerful technology tools used in brand management to improve the brand image by providing direct and interactive experience with the company's products and services which consecutively affects the customers' perception of the brand (Rondeau, 2005; Rohm et al., 2012). Mobile applications and services affect the brand image because they have strong effect on satisfying customers' expectations and needs (Chen and Ching, 2007). Providing mobile value-added services and mobile applications for customers to perform their daily transactions with the company will satisfy the customers' needs, engage them with the brand, and enhance the brand image (Wang and $\mathrm{Li}, 2012$ ). In addition, mobile applications and services are easily accessible and can be customized based on time, location, and personal preferences to provide better customer service and support (Strom et al., 2014). Hence, we hypothesize that:

H2. Mobile applications and services have a significant impact on brand image. 


\subsection{Social Media Applications}

Social media applications are new interactive and cost-effective technology tools that build virtual communities, create emotional experiences, and assist firms to improve their brand image by having better interaction and communication grounds with customers (Erdogmus and Cicek, 2012). By using social media applications, companies can easily advertise products and services to wide range of consumers, receive instant feedback from customers, and provide immediate online support (Kaplan and Haenlein, 2010). The real-time interaction and communication between customers and the company through social media create a good opportunity to improve the brand image (Mangold and Faulds, 2009). Customers usually consider other customers' comments and feedback about the company's products and services on social media applications before they make any purchasing decision (Torlak et al., 2014). Companies can use social media applications in their marketing strategies to provide real-time information, engage with consumers, and increase sales (Tiago and Verissimo, 2014). Therefore, we can hypothesize that:

H3. Social media applications have a significant impact on brand image.

\section{METHOD}

The study focuses on identifying technology-based applications affecting the brand image in telecommunications industry, determining the most influencing technology-based application that affects the brand image, and identifying the areas of improvement for each technology-based application. We selected Bahrain to conduct our research because only few similar research studies were conducted to investigate the effect of technology-based applications on brand image in the telecommunications industry. A questionnaire was used as the primary data collection instrument for this research study consisting of two main sections. The first section is demographic information about the target population such as age, gender, nationality, educational level, and employment status. The second section includes five-point Likert scale (ranging from $1=$ "Strongly Disagree" to $5=$ "Strongly Agree") questions or statements to measure the effect of websites, mobile applications \& services, and social media applications on the brand image in telecommunications sector.

To ensure the validity of the adapted questionnaire items, the questionnaire was examined and validated by three academic experts and few amendments were made on the questionnaire items based on their comments and feedback. The questionnaire was then pilot tested with 20 respondents to test the reliability of the research questions. Cronbach's $\alpha$ was utilized to examine the internal consistency of the hypothesized model. The result of Cronbach's $\alpha$ for research constructs used in this study is shown in the Table 1 . The Cronbach's $\alpha$ values for all research constructs are greater than 0.7 which means that the questionnaire items are considered acceptable according to Cavana et al. (2001).

Table 1. Reliability test results

\begin{tabular}{|l|l|l|l|}
\hline Construct & $\begin{array}{l}\text { Total } \\
\text { no. of } \\
\text { items }\end{array}$ & $\begin{array}{l}\text { Cronbach' } \\
\text { s } \alpha \\
\text { reliability }\end{array}$ & $\begin{array}{l}\text { Reliability } \\
\text { level }\end{array}$ \\
\hline
\end{tabular}

\begin{tabular}{|l|c|c|c|}
\hline & coefficient & \\
\hline Websites & 5 & 0.755 & Reliable \\
\hline $\begin{array}{l}\text { Mobile Applications } \\
\text { and Services }\end{array}$ & 5 & 0.734 & Reliable \\
\hline $\begin{array}{l}\text { Social Media } \\
\text { Applications }\end{array}$ & 5 & 0.823 & Reliable \\
\hline Brand Image & 5 & 0.795 & Reliable \\
\hline
\end{tabular}

The target population was identified as the customers of telecommunications companies in Bahrain which are estimated to be around 1 million. The convenience sampling approach was selected to collect the required research data from 500 customers that represent the targeted sample. The convenience sampling approach was adopted because of its simplicity and flexibility as the sample will be taken from customers who are easy to reach or contact. Among 500 questionnaires that were distributed online by different means, only 391 responses were received with a response rate of $78.2 \%$. From the collected responses, only 355 responses were considered to be valid for the research study after removing the incomplete and invalid responses.

The operationalization of research constructs is presented in Appendix A. The operationalization of Websites was adapted from Da Silva and Syed Alwi (2008), Lin and Lee (2012), Morgan-Thomas and Veloutsou (2013), and Cleff et al. (2018). It measures websites in terms of reliability/ease of use, usefulness, engagement/interaction/personalization, trust, and customer experience. The operationalization of Mobile Applications \& Services was adapted from Rohm et al. (2012) and Wang and Li (2012) that assess the following attributes: reliability/ease of use, usefulness, engagement/interaction/personalization, trust, and customer experience. The operationalization of Social Media Applications was adapted from Erdogmus and Cicek (2012) focusing on the following attributes: communication, interaction, giving feedback, sharing with family and friends, and engagement. Finally, the operationalization of Brand Image was adapted from Chen and Myagmarsuren (2011) and Balaji (2011).

\section{ANALYSIS AND RESULTS}

This section presents and discusses study findings including results of hypotheses testing. The tested variables are Websites, Mobile Applications \& Services, Social Media Applications, and Brand Image.

\subsection{Hypotheses Testing}

Table 2 represents the results of the multiple regression analysis for this research study. The $R$ value $=0.529$ which shows a positive relationship between the independent variables and brand image, while the $R^{2}$ value $=0.280$ which means that about $28 \%$ of the consumers' perception of the brand image is explained and justified by the independent variables which are technology-based applications

(Websites, Mobile Applications \& Services, and Social Media Applications). The $F$ test value $=45.433 \geqslant 1.96$ and the $\operatorname{Sig} F$ value $=0.000 \leqslant 0.05$. This signifies that the independent variables have a significant relationship with the dependent variable which means that the overall model test is significant. 
Table 2. Multiple regression analysis

\begin{tabular}{|l|l|l|l|}
\hline Independent variables & $\boldsymbol{B}$ & $\boldsymbol{t}$-test & Sig. \\
\hline Websites & 0.144 & 2.421 & 0.016 \\
\hline $\begin{array}{l}\text { Mobile Applications and } \\
\text { Services }\end{array}$ & 0.097 & 1.690 & 0.092 \\
\hline Social Media Applications & 0.393 & 7.688 & 0.000 \\
\hline $\boldsymbol{R}$ & 0.529 & \\
\hline $\boldsymbol{R}^{2}$ & 0.280 & \\
\hline $\boldsymbol{F}$ test & 45.433 & \\
\hline Sig F test & 0.000 & \\
\hline No. of observations & 355 & \\
\hline
\end{tabular}

\subsubsection{Websites}

For this variable, the $\beta$ value $=0.144$, the $t$-test value $=$ 2.421 , and the sig. ( $p$-value) $=0.016$. From these results, the first hypothesis in the research study should be accepted since the sig. $(p$-value) $=0.016 \leqslant 0.05$. In addition, the $\beta$ value for this variable $=0.144$ which indicates that this variable has a positive impact on brand image.

\subsubsection{Mobile Applications and Services}

For the second variable, the $\beta$ value $=0.097$, the $t$-test value is $=1.690$, and the sig. $(p$-value $)=0.092$. The results tell us that the second hypothesis in the research study should be rejected because the sig. $(p$-value $)=0.092 \geqslant 0.05$. However, the $\beta$ value for this variable $=0.097$ which indicates that this variable has a positive effect on brand image, but this impact is insignificant.

\subsubsection{Social Media Applications}

For the third variable, the $\beta$ value $=0.393$, the $t$-test value $=$ 7.688 , and the sig. ( $p$-value $)=0.000$. From these results, the third hypothesis in the research study should be accepted since the sig. ( $p$-value $)=0.000 \leqslant 0.05$. The $\beta$ value for this variable $=0.393$ which indicates that this variable has a positive impact on brand image. Furthermore, the significance value of this variable proves that this variable has the largest effect on the Brand Image as compared to other independent variables

The research findings are summarized in Table 3 . The table shows that two hypotheses were accepted, and one hypothesis was rejected from the three research hypotheses. Findings prove that both Websites and Social Media Applications have significant impact on the Brand Image of telecommunications companies in Bahrain. On the other hand, Mobile Applications \& Services hypothesis was rejected because its sig. $(p$-value $)=0.092) \geqslant 0.05$. Moreover, by comparing the values of $\beta$ for all independent variables, Social Media Applications variable has the highest $\beta$ value = 0.393 which indicates the highest impact on Brand Image.

Table 3. Summary of research hypotheses testing

\begin{tabular}{|l|l|l|l|}
\hline $\begin{array}{l}\text { Research } \\
\text { hypothesis }\end{array}$ & Decision & $\begin{array}{l}\text { Reason of } \\
\text { acceptance or } \\
\text { rejection }\end{array}$ \\
\hline $\begin{array}{l}\text { H1: Websites have a } \\
\text { significant impact } \\
\text { on brand image. }\end{array}$ & & Accept & $\begin{array}{l}\text { Supported at 5\% } \\
\text { significance level } \\
(\beta=0.144, \text { p-value } \\
=0.016)\end{array}$ \\
\hline $\begin{array}{l}\text { H2: Mobile } \\
\text { applications and } \\
\text { services have a } \\
\text { significant impact }\end{array}$ & & Reject & $\begin{array}{l}\text { Not supported at } \\
5 \% \text { significance } \\
\text { level }(\beta=0.097, \\
\text { p-value }=0.092)\end{array}$ \\
\hline
\end{tabular}

Supported at 5\%
significance level
$(\beta=0.393, p$-value
$=0.000)$

\section{DISCUSSION AND IMPLICATIONS}

The research findings were able to give explanation on the effect of technology-based applications on brand image in the telecommunications industry. The first construct proposed in the conceptual model is Websites. The findings show that majority of consumers are frequent users of websites provided by their telecommunications companies. This reflects a high level of reliability of website and online environment. Customers depend on website as the main tool to find information about the company's products and services (Cleff et al., 2018). This was highly supported by the research findings as large percentage of customers confirmed their dependency on websites to search for firm's products and services. According to the research results, a considerable percentage of customers believe that websites provide active engagement with the brand through interaction, entertainment, and personalization. Former research studies showed similar finding as websites open the doors for active engagement with the brand, and interactivity between customers and the brand. This in turn will create emotional connection between the customer and the brand which will enhance the brand image (Morgan-Thomas and Veloutsou, 2013; Cleff et al., 2018). Online brand trust, security, and privacy are other aspects of the effect of websites on the brand image as emphasized by other previous studies (Da Silva and Syed Alwi, 2008; Lin and Lee, 2012). The research findings support earlier studies since majority of customers demonstrated their willingness to trust the websites and online services by sharing their personal details and making payments online. The research results also correlate with literature studies on enhancing and improving the customer experience with the brand through websites (Morgan-Thomas and Veloutsou, 2013; Cleff et al., 2018).

The second construct proposed in the conceptual model is Mobile Applications and Services. Although research findings showed that this construct has insignificant impact on brand image, but it still exerts some positive effect on the brand image. As examined by former research studies, mobile applications and services help firms to engage with customers in interactive real-time experience with the brand and stimulate positive feelings about the brand image. In addition, the level of trust with the brand can be improved through mobile applications and services for performing transactions and making online payment (Wang and Li, 2012; Strom et al., 2014). The research findings showed a positive impact on brand image similar to former research studies; however, this effect or impact was not sufficient to justify the effect of mobile applications \& services on the brand image in the telecommunications sector.

The third and the last construct in the model is Social Media Applications which has the highest significant effect on brand image. These results are in consensus with other research studies from literature. 
For example, majority of customers showed their interest in following telecommunications brands on social media applications while a considerable percentage of customers confirmed that they prefer social media applications for communication and interaction with the brand. According to Kaplan and Haenlein (2010), companies can provide immediate support to customers and receive instant feedback from them about their branded products and services. This was supported by the study results since more than $50 \%$ of customers declared that they are willing to give feedback about their experience with the company's products and services on social media applications. However, only few customers showed their willingness to share the company's posts and advertisements on social media applications with their family and friends. Furthermore, the study results partially correlate with the findings of Erdogmus and Cicek (2012) that companies can benefit from social media applications by engaging the customers through interactive campaigns, games, and participatory discussions.

\subsection{Theoretical Implications}

Current study findings show significant relationships between websites and social media applications, and the brand image and less significant relationship between mobile applications \& services and the brand image. Thus, researchers should build up on the significant relationships of technology-based applications on the brand image and investigate further on the weak or insignificant relationships between some technology-based factors and the brand image. Additionally, the research study contributes to the academic literature especially for university students and future researchers interested in digital marketing and brand management.

\subsection{Managerial Implications}

The key contribution of this research paper resides behind the significance of using technology-based applications in influencing the customers' perceptions of the company's products and services and hence the company's brand image. The research study provides insights on how business organizations should plan their marketing strategies to influence the consumers' perceptions of their brands. By strengthening and improving the brand image, marketers can reach out more customers easily, and consequently contribute to raising the sales revenue of their products and services and decreasing the churn rate of their customers. Furthermore, if companies developed smart strategies and focused their attention on technology-based applications including websites, mobile applications, and social media applications instead of wasting time and money on obsolete traditional channels, the brand awareness and engagement with the brand will increase which will help the companies in competing their rivals in the marketplace.

\section{CONCLUSION}

Research findings and hypotheses testing results have successfully assessed the impact of technology-based applications (websites, mobile applications \& services, and social media applications) on the brand image in the telecommunications industry. Both websites and social media applications were found to have significant positive impact on the brand image while mobile applications and services have positive but insignificant impact on the brand image. In addition, the results revealed that the most influencing technology-based application that has the highest

impact on the brand image in the telecommunications sector is social media applications. Finally, the research results and analysis identified the areas of improvement for each technology-based application when used to improve the brand image. Such areas of improvement include: engaging customers with the brand through websites and mobile applications, providing interactive contents and personalization, providing real-time customer experience with the brand through websites and online services, promoting mobile applications and services provided by the company through smart marketing campaigns and customers' awareness, motivating customers to share the company's posts on social media applications with family and friends, and finally offering interactive games, competitions, and campaigns for customers through social media applications.

This research can add significant contribution to the findings of previous research studies since it provides a detailed analysis with statistical figures on how technology-based applications can impact the brand image of companies in the minds of customers. It provides a clear guidance for marketers on the main technology-based applications that should be employed to enhance the brand image of firms as well as the main areas of improvement that can be considered by companies when using technology-based applications as branding tool. It paves new ways toward the improvement of digital marketing strategies and the enforcement of technology-based channels instead of the traditional channels in today's competitive marketplace. The findings of the research paper can be valuable for all service-based companies in general, and for telecommunications companies in particular.

Three technology constructs were used only as there might be more technology-based applications or factors that can be added into the scope of the research. The quantitative method adopted in this study could not provide detailed information on why technology-based applications would impact the brand image. The research was based on single cross-sectional analysis and did not investigate the issue from longitudinal perspective. For future research studies, the scope can be extended by increasing the number of technology-based applications or factors that could impact the brand image of companies.

In addition, the quantitative approach might be combined with qualitative approach to investigate why and how would technology affect the brand image of companies, and thus provide comprehensive and detailed analysis from both quantitative and qualitative perspectives. Other data collection techniques could be used in future studies such as structured interviews. Finally, future research may further investigate the problem statement from a longitudinal point of view.

\section{APPENDIX A: OPERATIONALIZATION OF CONSTRUCTS}

\begin{tabular}{|c|c|c|}
\hline Constructs & Item description & Source \\
\hline \multirow[t]{2}{*}{ Websites } & $\begin{array}{l}\text { I frequently use the website and online } \\
\text { services provided by my telecom } \\
\text { brand. }\end{array}$ & \multirow{2}{*}{$\begin{array}{l}\text { Da Silva and Syed } \\
\text { Alwi (2008), Lin } \\
\text { and Lee (2012), } \\
\text { Morgan-Thomas } \\
\text { and Veloutsou } \\
\text { (2013), Cleff et al. }\end{array}$} \\
\hline & $\begin{array}{l}\text { I use the website to find information } \\
\text { about the company's products and } \\
\text { services. }\end{array}$ & \\
\hline
\end{tabular}




\begin{tabular}{|c|c|c|}
\hline & $\begin{array}{l}\text { The website helps me to engage with } \\
\text { the brand through interactive contents, } \\
\text { entertainment, and personalization. }\end{array}$ & (2018) \\
\hline & $\begin{array}{l}\text { I trust my telecom brand by sharing } \\
\text { personal information or making } \\
\text { payments through website and online } \\
\text { services. }\end{array}$ & \\
\hline & $\begin{array}{l}\text { Company's website and online } \\
\text { services provide me with online } \\
\text { customer experience with the brand. }\end{array}$ & \\
\hline $\begin{array}{l}\text { Mobile } \\
\text { Applications } \\
\text { \& Services }\end{array}$ & $\begin{array}{l}\text { I regularly use mobile apps and other } \\
\text { mobile services (e.g. Interactive Voice } \\
\text { Response, Short Codes) to complete } \\
\text { my transactions. }\end{array}$ & $\begin{array}{l}\text { Rohm et al. } \\
\text { (2012) and Wang } \\
\text { and Li (2012) }\end{array}$ \\
\hline & $\begin{array}{l}\text { I feel that my personal needs are met } \\
\text { when using mobile apps and mobile } \\
\text { services provided by my telecom } \\
\text { company. }\end{array}$ & \\
\hline & $\begin{array}{l}\text { Mobile apps and mobile services } \\
\text { provide active engagement with the } \\
\text { brand through interactive contents and } \\
\text { enjoyment. }\end{array}$ & \\
\hline & $\begin{array}{l}\text { I trust mobile apps and mobile } \\
\text { services provided by my telecom } \\
\text { brand. }\end{array}$ & \\
\hline & $\begin{array}{l}\text { Mobile apps and mobile services } \\
\text { provide me with real-time customer } \\
\text { experience with the brand. }\end{array}$ & \\
\hline $\begin{array}{l}\text { Social } \\
\text { Media } \\
\text { Applications }\end{array}$ & $\begin{array}{l}\text { I am interested in following telecom } \\
\text { brands on social media applications } \\
\text { (e.g. Instagram, YouTube, Twitter). }\end{array}$ & $\begin{array}{l}\text { Erdogmus and } \\
\text { Cicek (2012) }\end{array}$ \\
\hline & $\begin{array}{l}\text { I prefer social media applications for } \\
\text { communication and interaction with } \\
\text { my telecom brand. }\end{array}$ & \\
\hline & $\begin{array}{l}\text { I am willing to give feedback about } \\
\text { my telecom brand products and } \\
\text { services on social media. }\end{array}$ & \\
\hline & $\begin{array}{l}\text { I share the company's posts on social } \\
\text { media with my family and friends. }\end{array}$ & \\
\hline & $\begin{array}{l}\text { My telecom brand offers interactive } \\
\text { competitions, games, and campaigns } \\
\text { on social media. }\end{array}$ & \\
\hline $\begin{array}{l}\text { Brand } \\
\text { Image }\end{array}$ & $\begin{array}{l}\text { I prefer selecting my telecom service } \\
\text { provider based on its brand name. }\end{array}$ & $\begin{array}{l}\text { Chen and } \\
\text { Myagmarsuren, }\end{array}$ \\
\hline & $\begin{array}{l}\text { My telecom service provider has a } \\
\text { good image in the minds of customers. }\end{array}$ & $\begin{array}{l}\text { (2011) and Balaji } \\
\text { (2011) }\end{array}$ \\
\hline & $\begin{array}{l}\text { Technology applications help me in } \\
\text { increasing my awareness and } \\
\text { interaction with the telecom brand. }\end{array}$ & \\
\hline & $\begin{array}{l}\text { I would repurchase the products or } \\
\text { services of my telecom brand again. }\end{array}$ & \\
\hline & $\begin{array}{l}\text { I would recommend the products or } \\
\text { services of my telecom brand to } \\
\text { others. }\end{array}$ & \\
\hline
\end{tabular}

\section{REFERENCES}

1. Ansari, A. and Riasi, A. (2016), "An investigation of factors affecting brand advertising success and effectiveness", International Business Research, Vol. 9 No. 4, pp. 20-30.

2. Balaji, M.S. (2011), "Building Strong Service Brands: The Hierarchical Relationship Between Brand Equity Dimensions", IUP Journal of Brand Management, Vol. 8 No. 3, pp. 7-24.

3. Broyles, S.A., Schumann, D.W. and Leingpibul, T. (2009), "Examining brand equity antecedent/consequence relationships", Journal of Marketing Theory and Practice, Vol. 17 No. 2, pp. 145-162.

4. Cavana, R.Y., Delahaye, B.L. and Sekaran, U. (2001), Applied business research: Qualitative and quantitative methods, John Wiley \& Sons Australia.

5. Chen, C.F. and Myagmarsuren, O. (2011), "Brand equity, relationship quality, relationship value, and customer loyalty: Evidence from the telecommunications services", Total Quality Management \& Business Excellence, Vol. 22 No. 9, pp. 957-974.

6. Chen, J.S. and Ching, R.K. (2007), "The effects of mobile customer relationship management on customer loyalty: brand image does matter", In 2007 40th Annual Hawaii International Conference on System Sciences (HICSS'07) (pp. 151b-151b). IEEE.
7. Cleff, T., Walter, N. and Xie, J. (2018), "The Effect of Online Brand Experience on Brand Loyalty: A Web of Emotions", IUP Journal of Brand Management, Vol. 15 No. 1, pp. 7-24

8. Da Silva, R. and Syed Alwi, S. (2008), "Online brand attributes and online corporate brand images", European Journal of Marketing, Vol. 42 No. 9/10, pp. 1039-1058.

9. Davis, F.D. (1989), "Perceived usefulness, perceived ease of use, and user acceptance of information technology", MIS quarterly, Vol. 13 No. 3, pp. 319-340.

10. De Chernatony, L. and Christodoulides, G. (2004), "Taking the brand promise online: challenges and opportunities", Interactive Marketing, Vol. 5 No. 3, pp. 238-251.

11. Dichter, E. (1985), "What's in an image", Journal of consumer marketing, Vol. 2 No. 1, pp. 75-81.

12. Dobni, D. and Zinkhan, G.M. (1990), "In search of brand image: A foundation analysis", Advances in Consumer Research, Vol. 17 pp. 110-119.

13. Eid, R., Al Sharief, R.Y. and Hussein, L. (2011), "Factors Affecting the Success of Online Branding: An Empirical Study", International Journal of Online Marketing (IJOM), Vol. 1 No. 4, pp. 20-32.

14. Erdogmus, I.E. and Cicek, M. (2012), "The impact of social media marketing on brand loyalty", Procedia-Social and Behavioral Sciences, Vol. 58 pp. 1353-1360.

15. Janonis, V. and Virvilaite, R. (2007), "Brand image formation", Engineering economics, Vol. 52 No. 2, pp. 78-90.

16. Jones, C. and Bonevac, D. (2013), "An evolved definition of the term 'brand': Why branding has a branding problem", Journal of brand strategy, Vol. 2 No. 2, pp. 112-120.

17. Kalra, S. (2016), "Investigating Relationship between Brand Image, Brand Credibility and Brand Equity", Review of Professional Management, Vol. 14 No. 2, pp. 24-33.

18. Kaplan, A.M. and Haenlein, M. (2010), "Users of the world, unite! The challenges and opportunities of Social Media", Business horizons, Vol. 53 No. 1, pp. 59-68

19. Keller, K.L. (2001), Building customer-based brand equity: A blueprint for creating strong brands (pp. 3-27). Cambridge, MA Marketing Science Institute.

20. Keller, K.L. (2009), "Building strong brands in a modern marketing communications environment", Journal of marketing communications, Vol. 15 No. 2-3, pp. 139-155.

21. Kollmann, T. and Suckow, C. (2008), "Sustaining the brand idea in electronic environments", International Journal of Business Environment, Vol. 2 No. 2, pp. 153-167.

22. Kwon, W.S. and Lennon, S.J. (2009), "What induces online loyalty? Online versus offline brand images", Journal of Business Research, Vol. 62 No. 5, pp. 557-564.

23. Lin, M.Q. and Lee, B.C. (2012), "The influence of Website environment on brand loyalty: Brand trust and brand affect as mediators", International Journal of Electronic Business Management, Vol. 10 No. 4, pp. 308-321.

24. Mangold, W.G. and Faulds, D.J. (2009), "Social media: The new hybrid element of the promotion mix", Business horizons, Vol. 52 No. 4, pp. 357-365.

25. Merrilees, B. and Fry, M.L. (2002), "Corporate branding: a framework for e-retailers", Corporate Reputation Review, Vol. 5 No. 2-3, pp. 213-225.

26. Morgan-Thomas, A. and Veloutsou, C. (2013), "Beyond technology acceptance: Brand relationships and online brand experience", Journal of Business Research, Vol. 66 No. 1, pp. 21-27.

27. Rohm, A.J., Gao, T.T., Sultan, F. and Pagani, M. (2012), "Brand in the hand: A cross-market investigation of consumer acceptance of mobile marketing", Business Horizons, Vol. 55 No. 5, pp. 485-493.

28. Rondeau, D.B. (2005), "For mobile applications, branding is experience", Communications of the ACM, Vol. 48 No. 7, pp. 61-66.

29. Schivinski, B. and Dabrowski, D. (2016), "The effect of social media communication on consumer perceptions of brands", Journal of Marketing Communications, Vol. 22 No. 2, pp. 189-214.

30. Strom, R., Vendel, M. and Bredican, J. (2014), "Mobile marketing: A literature review on its value for consumers and retailers", Journal of Retailing and Consumer Services, Vol. 21 No. 6, pp. 1001-1012.

31. Tiago, M. and Verissimo, J. (2014), "Digital marketing and socia media: Why bother?”, Business Horizons, Vol. 57 No. 6, pp. 703-708.

32. Torlak, O., Ozkara, B.Y., Tiltay, M.A., Cengiz, H. and Dulger, M.F. (2014), "The effect of electronic word of mouth on brand image and purchase intention: An application concerning cell phone brands for youth consumers in Turkey", Journal of Marketing Development and Competitiveness, Vol. 8 No. 2, pp. $61-68$ 
33. Wang, W.T. and Li, H.M. (2012), "Factors influencing mobile services adoption: a brand-equity perspective", Internet Research, Vol. 22 No. 2, pp. 142-179.

\section{AUTHORS PROFILE}

Husain Abdulaal (MBA graduate, Ahlia University) is an IT Professional who holds a Bachelor Degree in Computer Science from the University of Bahrain and PMP certification from Project Management Institute (PMI). His main research interests are in the areas of digital marketing, brand management, information technology, and project management.

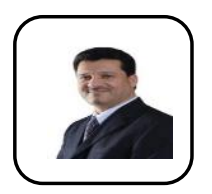

Muneer Al Mubarak (PhD, University of Leeds; MBA, Durham University) is an Associate Professor of Management and Marketing, VP for Admin \& Finance and Acting Dean of Student Affairs, at Ahlia University. His main research interests are in the areas of SMEs, corporate social responsibility, corporate governance, relationship marketing, competitive advantage, CRM, entrepreneurship and international business relations. 